\title{
AMBIGUITAS MEDIA DALAM MASYARAKAT: PERTARUNGAN ANTARA AS IT IS \& AS OUGHT TO BE
}

\author{
Inri Inggrit W. \\ Jurusan Ilmu Komunikasi, Fakultas Ilmu Komunikasi \\ Universitas Kristen Petra \\ Jalan Siwalankerto 121-131 Surabaya 60236 \\ Email: inggrit@peter.petra.ac.id
}

\begin{abstract}
Information and Communication Technologies is the effect of globalization, thus makes media become an actor for trasformation and the rapidth of communication stream. In Indonesia, democratization that had been began by reformation in 1998 then as a proof of the strengthness of information technology that was succed bringing the great changes for Indonesian politic. The fall of The New Order in 1998, could not be separated from the role of internet which at that time offered the public sphere and the freedom to receive and exchange information without government intervention. The history of the journey of media, including Indonesia, media often face a dilema. Media was experiencing an ambiguty, facing the conflict of interest between as ought to be and as it is. Will media keep their ideal function as the icon of democratization that provide information for reaching transparation and partisipation of society in policy making process? It is related to the freedom of information for society. Media are also expected to be conistent for always acomodating varies opinions or inputs of society. In other side, media are controled by capitalism which then makes media to serve the capitalis's interest as well as make a priority for the economy aspect in producing the information.
\end{abstract}

Keywords: Globalization, Freedom of Information, Public Sphere, Media Capitalism.

\section{PENDAHULUAN}

Democracy forever teases us with the contrast between its ideals and its realities, between its heroic possibilities and its sorry achivement

\section{(Agnes Repplier)}

Pada ujung akhir abad XX ada dua fenomena dunia yang sama dahsyat. Yang pertama kemajuan ilmu pengetahuan dan teknologi yang membawa pengaruh luar biasa pada komunikasi dan informasi. Demikian dahsyat sehingga sanggup menjangkau seluruh bagian dari bumi kita. Kedua, globalisasi dunia telah menimbulkan koreksi pasar berbagai negara di Asia yang melahirkan krisis moneter dahsyat dan menghancurkan hasil-hasil pembangunan Indonesia selama 32 tahun. ${ }^{1}$

1 J. Kartini Soedjendro, "Tokoh Wibisana, Figur Seorang Nasionalis", dalam http://www. suaramerdeka.com/harian/0205/18/kha2.htm 
Perdebatan tentang pengaruh globalisasi terhadap negara-bangsa (nation-state) nampaknya belum juga usai. Pandangan umum yang berkembang menyatakan bahwa globalisasi mendorong lahirnya organisasi modern yang semakin homogen serta berorientasi pada efektifitas dan efisiensi. Nation-state dikatakan juga akan mengalami perubahan institusional karena mengadopsi aturan-aturan institusional baru yang menjadi model dalam masyarakat dunia. Dengan demikian banyak yang meyakini bahwa globalisasi pada akhirnya akan melahirkan struktur organisasi yang sama di semua nation-state karena diadopsinya model-model tersebut. ${ }^{2}$

Globalisasi diyakini banyak pihak sebagai rangkaian proses yang sifatnya multidimensional dalam aspek sosial, ekonomi, politik, kultural yang bergerak secara ekstensif dan intensif ke dalam kehidupan masyarakat dunia. Rumusan globalisasi semacam inilah yang diyakini Anthony Giddens sebagai proses yang mengatasi ruang dan waktu. Ekstensif berarti bahwa perubahan tersebut menjangkau wilayah geografis yang nyaris tak terbatas, sedangkan intensif berarti bahwa perubahan tersebut juga terjadi dalam wilayah kehidupan sehari-hari.

Demikian pula halnya dengan globalisasi komunikasi yang memungkinkan lepasnya sekat-sekat antar negara dan mengeliminasi batas-batas nasionalisme yang kemudian ditransformasikan menjadi domain global. Fenomena ini mengaminkan apa yang dulu pernah diperkenalkan oleh McLuhan dengan global village. Bahwa dunia akan melebur menjadi satu. Tidak ada lagi sudut di dunia ini yang terisolasi karena semuanya telah dihubungkan dengan jaringan komunikasi global, komunikasi itu tidak saja menembus batas-batas wilayah tetapi juga budaya bahkan menipiskan batas personal.

Percepatan arus globalisasi komunikasi tentu saja tidak dapat dipisahkan dari peranan media dalam masyarakat. Pada awal kelahirannya, media dianggap sebagai salah satu manifestasi modernisasi. Sejalan dengan bergulirnya globalisasi komunikasi, media tumbuh dan berkembang semakin pesat. Kehadiran internet atau media on-line sebagai new media misalnya, menambah maraknya arus informasi. Pada 'masa keemasan' inilah masyarakat dunia ingin mewujudkan sebuah era peradaban baru yang disebut dengan information society. Yaitu, hadirnya suatu masyarakat informasi berbasis IT (information technology) yang menggerakkan setiap sendi kehidupan dengan aktivitas pertukaran informasi luar biasa intensnya.

Di Indonesia, internet merupakan media yang memberikan kontribusi tak ternilai bagi perjuangan para reformis di tahun 1998 ketika tidak memungkinkan lagi bagi mereka 'bersuara' lewat media komunikasi lainnya. Karakteristik yang dimiliki oleh media ini membuatnya menjadi superior dibanding conventional media yang sebelumnya sudah ada. Pertama adalah biaya penggunaan yang relatif murah. Kedua adalah sifatnya yang real time. Ketiga adalah sifatnya yang borderless. Tidak ada sekat-sekat ruang di media ini yang memungkinkan tiap orang dapat saling terkoneksi dengan baik. Keempat, dan ini yang paling penting, internet menyediakan ruang-ruang publik yang tidak dapat ditembus oleh otoritas penguasa. Ketika Tempo dibredel oleh Harmoko atas nama penguasa Orde Baru, bukan berarti kematian bagi

${ }^{2}$ Nanang Indra Kurniawan, "Masyarakat Dunia, Globalisasi dan Nation State" dalam "Kritik Globalisasi \& Neoliberalisme", hal. 17 
Tempo. Internet lalu menjadi alternatif yang sangat jitu dalam penyebaran beritaberita politik aktual oleh Tempo. ${ }^{3}$

Pelaksanaan demokrasi di suatu negara tidak dapat dilepaskan dari penyerapan teknologi informasi negara tersebut. Demikian pula dengan teknologi informasi, tidak dapat bergulir dari suatu tempat ke tempat lain bila tanpa globalisasi komunikasi. Hal ini berarti bahwa sistem demokrasi yang baik pada situasi tertentu akan sangat tergantung pada teknologi misalnya adalah teknologi telekomunikasi yang digunakan dalam proses penyebaran berita-berita politik yang merupakah hak setiap warga negara, sebagai media yang memotret visi-misi dalam pemilihan umum, sebagai kompas atau penunjuk suara rakyat, dll. Fenomena ini seperti mengingatkan aporisma populer yang dicetuskan McLuhan, "The medium is the message".

Tulisan ini akan mencoba untuk menyajikan rangkaian tentang relasi globalisasi komunikasi dan pelaksanaan demokrasi di Indonesia. Globalisasi komunikasi tentu saja tidak dapat dipisahkan dari sebuah entitas yang bernama media. Bagaimana memainkan perannya dalam masyarakat yang demokratis serta isue-isue yang diusung oleh media dalam menciptakan civil society menjadi menarik untuk diamati. Dua wajah media bagaikan Dewa Jenus melukiskan dualisme peran yang dimainkan media, yakni apa yang seharusnya (as ought to be) dan realitas yang terjadi (as it is) menjadi pertanyaan yang tak terjawab oleh waktu.

\section{PEMBAHASAN}

\section{Idealisme \& Media (As Ought To Be)}

Brian McNair mengemukakan ada lima fungsi media dalam masyarakat yang demokratis, yaitu:

"Firstly, they must inform citizens of what is happening around them. Secondly, they must educate as to the meaning and significance of the facts. Thirdly, the media must provide a platform for public political discourse, facilitating the formation of 'public opinion', and feeding that opinion back to the public from whence it came. The media's fourth function is to give publicity to governmental and political institutions. Finally, the media in democratic societies serve as a channel for the advocacy of political viewpoints."4

Hal yang serupa dikemukakan oleh Joh Delane, seorang editor majalah The Times yang mengungkapkan bahwa,

The first duty of the press is to obtain the earliest and most corect intelligence of the events of the time and instantly by disclosing them to make the common property of the nation. The press lives by disclosures....bound to tell the truth as we find it without fear of consequences-to lend no convenient shelter to acts of injustice and oppression, but to consign them to the judgment of the world...the duty of the journalist is the same as that of the historian-to seek out truth, above all things,

\footnotetext{
${ }^{3}$. www.theindonesianinstitute.org, diakses tanggal 6 pukul 10.10 WIB.

${ }^{4}$ Brian McNair, "An Introduction To Political Communication", hal. 21-22.
} 
and to present to his readers not such things as statecraft wouls wish them to know, but the truth as near as he can attain it. ${ }^{5}$

Dennis McQuail juga menerangkan adanya perubahan yang terjadi secara cepat dalam lingkungan di sekitar media membangkitkan peran signifikan media : its near universality of reach, great popularity and public character', yang berdampak pada kehidupan politik dan budaya. Selanjutnya ia mengatakan bahwa,

"In respect of politics, the mass media have gradually become : first, an essential element in the process of democratic politics by providing an arena and channel for wide debate, for making candidates for office widely known and for distributing diverse information and opinion. Second, a means of exercising power by virtue of the relatively privileged access that politicians and agents of a governmen can claim from the media as a legitimate right". ${ }^{6}$

Pada bagian inilah akan dibahas realitas apa yang seharusnya terjadi dalam globalisasi komunikasi dalam kaitannya dengan proses demokratisasi di Indonesia. Di sini akan diuraikan bagaimana sisi ideal yang dimainkan oleh media untuk mendukung terciptanya masyarakat yang madani.

\section{FOI: Dari Wacana Menuju Pada Realita}

Keterlibatan masyarakat atau warga negara dalam konteks demokratisasi dan media yang berkembang dewasa ini di Indonesia adalah adanya Freedom Of Information (FOI) atau Kebebasan Memperoleh Informasi Publik. Hak untuk memiliki kebebasan memperoleh informasi, dipegang oleh badan pemerintah, sekarang diakui secara luas sebagai salah satu hak asasi manusia. Ada kecenderungan yang besar sekali di dunia untuk mengakui secara sah hak itu karena negara-negara di seluruh dunia yang bercita-cita menjadi bangsa yang demokratis telah mengesahkan atau sedang menyusun UU kebebasan memperoleh informasi. ${ }^{7}$

Sebagai salah satu upaya untuk mendorong terciptanya pemerintahan yang demokratis (democratic government), transparansi (open government) serta penghargaan terhadap HAM (humas rights) maka dibutuhkan jaminan bagi masyarakat untuk mengamati perilaku pejabat dalam menjalankan fungsi publiknya (rights to observe/to attend public meeting), hak atau akses publik atas informasi (freedom of information), hak untuk berpatisipasi serta hak publik untuk dilindungi dalam mengungkap fakta dan kebenaran (whistle blower protection).

Kebebasan memperoleh informasi untuk kepentingan publik merupakan elemen penting untuk mengoptimalkan pengawasan publik terhadap pelaksanaan roda organisasi pemerintahan dan lembaga-lembaga negara lainnya untuk mendorong pemerintahan yang akuntabel sehingga mampu meningkatkan kompetensi dan efisiensi. Hak anggota masyarakat untuk memperoleh informasi merupakan faktor penting dalam meningkatkan kualitas pelibatan masyarakat dalam proses pengambilan publik (public policy making process). Pelibatan masyarakat tidak akan

\footnotetext{
5 John Delane dalam Eric Louw, "The Media and Political Process", hal. 61.

${ }^{6}$ Dennis McQuail, "McQuail's Mass Communication Theory”, hal. 30.

${ }^{7}$ Toby Mendel. "Kebebasan Memperoleh Informasi, Sebuah Survei Perbandingan Hukum”, hal. ii.
} 
banyak berarti apabila tanpa jaminan kebebasan memperoleh informasi tersebut. Teknologi komunikasi yang diadopsi oleh pemerintah dalam hal ini berperan mendorong upaya tersebut.

Oleh kaum Neo-futuris, relasi antara globalisasi komunikasi dengan politik, dilihat sebagai sesuatu yang tak dapat dihindarkan. Kelompok ini melihat bahwa perkembangan teknologi komunikasi berpengaruh terhadap proses politik. Bahkan kemajuan komunikasi digital dengan e-mail akan membawa pada pemberian semangat baru bagi demokrasi. Dengan meminjam optimisme dari Nicholas Negroponte, salah satu tokoh kelompok Neo-futuris yang menegaskan bahwa 'menjadi digital' adalah sesuatu yang utama dalam kehidupan politik yang sehat pada dewasa ini. Neo-futuris meyakini bahwa saat ini masyarakat telah memasuki suatu era penemuan yang baru di mana tersedianya piranti-piranti ditempatkan secara langsung untuk mengimbangi institusi-institusi demokrasi.

Demokrasi yang kuat membutuhkan kekuatan jaringan interaksi antara negara dan masyarakat, antara pemerintah dan yang diperintah. Fenomena ini merupakan potensi bagi lahirnya demokrasi digital, adanya kemampuan interaktif Information and Communication Technologies (ICTs) yang mengatasi batas waktu dan ruang, memfasilitasi arus informasi dari pemerintah dan warga negara serta menghubungkan secara langsung umpan balik masyarakat dan tingkat partisipasi mereka dalam penyelenggaraan pemerintahan. Melalui hal tersebut, diharapkan tercipta hubungan yang prospektif antara pemerintah pusat dan pemerintah lokal untuk membangun interaksi dengan rakyat lewat situs, $e$-mail dan kios-kios informasi publik. 8

Di Indonesia, wacana FOI telah menjadi pada realita pada tahun 2008 lalu walaupun dalam pelaksanaannya masih menunggu sampai 2010. Implementasi UU ini mendorong internet berperan sebagai media utama yang memfasilitasi akses bagi terbukanya informasi dari pemerintah kepada publik. FOI memungkinkan terjadinya transparansi kepada masyarakat luas untuk mengetahui mekanisme jalannya pemerintahan dan berpartisipasi dalam pengambilan keputusan. Sekali lagi, peranan media menjadi sangat besar, terutama untuk mengungkapkan praktek-praktek kolusi dan korupsi pejabat negara. Di sinilah, peran jurnalisme investigatif menjadi penting untuk dilakukan media.

Dengan pemanfaatan ICTs maka secara otomatis mendorong skill masyarakat untuk berkembang dalam penggunaan teknologi informasi. Masalah ini tentu tidak mudah tanpa didorong niat baik pemerintah. Sebab sampai saat ini di Indonesia, masyarakat masih dipusingkan dengan kebutuhan fisiologis sehingga perlu dilakukan edukasi pemberdayaan dan pemanfaatan teknologi informasi sebagai kebutuhan warga negara.

\section{Ketersediaan Ruang Publik atau Public Sphere}

Gagasan mengenai kebebasan politik dan pemberdayaan warga negara merupakan akar dari lahirnya ide tentang ruang publik (public sphere). Beberapa pengamat seringkali mengungkapkan peran media sebagai ruang debat publik namun dalam realitanya, media-media tradisional hanya mencerminkan relasi top

\footnotetext{
${ }^{8}$ Ibid, hal. 13.
} 
down, paternialistik, one to many serta tidak menunjukkan arah demokratisasi. Dukungan dari arus liberalisasi, philosofi-philosofi komunitarian dan usahawan, munculnya ICTs seperti telematika berdampak pada berkurangnya diskursus yang hierarkhis. Hal ini ditandai dengan munculnya tingkat partisipasi masyarakat yang semakin intensif, adanya keterbukaan, transaparansi serta keberpihakan pada publik. ${ }^{9}$

Dalam pandangan Jurgen Habermas sebagai pencetus "public sphere", dalam ruang publik terdapat sikap toleransi antar warga negara terhadap yang lainnya berdasarkan hak dan kewajiban yang sama sehingga tidak ada ruang bagi otoritas tertentu yang diperbolehkan secara sepihak menentukan batas-batas, apa yang dapat diterima dan apa yang tidak. Habermas menekankan pentingnya toleransi dan konsensus dalam masyarakat demokratis atau global. Toleransi harus dipandang secara positif baik etis maupun politis. Ia dipandang secara etis karena mengandaikan kebenaran dari yang lain. Ia dipandang secara politis karena mampu membentuk konsensus. Gagasan Habermas ini menekankan pentingnya demokrasi konstitusional sebagai satu-satunya sistem yang dapat mengakomodasi komunikasi bebas dominasi dari pihak manapun termasuk penguasa.

Ruang publik berfungsi sebagian sebagai ruang-ruang yang merupakan tempat penduduk dari suatu negara datang bersama untuk menyuarakan dan memformulasikan kebutuhan-kebutuhan politik mereka. Ruang publik politik mewakili saluran-saluran vital dalam masyarakat sipil, di mana individu-individu dan kelompok-kelompok bisa diinformasikan mengenai permasalahan kemudian mendiskusikan dan berdebat mengenai pokok-pokok permasalahan tersebut dengan bebas dan merdeka sehingga pada akhirnya mereka memiliki pengaruh pada agendaagenda kebijakan. ${ }^{10}$

Anthony Wilhelm membagi ruang publik politik ke dalam empat bagian yang pokok, ${ }^{11}$ ciri khusus pertama yang didiskusikan adalah kepemilikan sumber-sumber terdahulu, keahlian-keahlian dan kapasitas-kapasitas yang dibawa oleh seseorang ke meja untuk mencapai pemfungsian (politik) tertentu. Sehubungan dengan perhatian bagi pembangunan kapasitas manusia yang merupakan kebutuhan untuk meyakinkan bahwa semua orang secara potensial terpengaruhi oleh suatu kebijakan, kesempatan untuk mengekspresikan pilihan mereka dan mempengaruhi kebijakan yang hal dimiliki melalui peralatan-peralatan telekomunikasi yang maju. Karakter ini yang disebut dengan inclusiveness/keterlibatan, merefleksikan komitmen yang telah lama berlangsung dalam susunan sosial demokrasi untuk keikutsertaan universal dalam pembuatan keputusan politik. Ciri khusus yang ke tiga dari kehidupan publik yang bermedia digital adalah kebebasan, yaitu mengemukakan ide-ide dab opini-opini seseorang untuk pemberian kekuatan hukum. Desain adalah karakteristik ke empat dari kehidupan politik virtual, suatu istilah luas yang mencakup arsitektur suatu network, termasuk apakah suatu network itu bersifat interaktif, tenang, aman dan

${ }^{9}$ Barry N. Hague \& Brian D. Loader, "Digital Democracy: Discource and Decision Making In The Information Age", hal. 23.

${ }^{10}$ Anthony Wilhelm, "Demokrasi Di Era Digital, Tantangan Kehidupan Politik di Ruang Cyber", hal. xxxiii.

${ }^{11}$ Ibid, hal. 40. 
tidak disensor dengan kapasitas yang cukup yang dilestarikan guna tujuan-tujuan non-komersial.

Dalam suatu masyarakat yang demokratis, pembentukan opini dan pembuatan keputusan adalah sesuatu yang dianggap sah ketika pembentukan tersebut mewakili keinginan orang-orang, yang didefinisikan bukan sebagai harapan-harapan dari semua orang yang secara potensial terpengaruh oleh suatu kebijakan. Untuk meyakinkan urusan kenegaraan ini, perlu untuk menciptakan keadaan-keadaan dalam masyarakat di mana setiap orang yang ingin berpatisipasi dalam ruang publik, memiliki kesempatan untuk menyuarakan perhatian, kebutuhan dan pilihan mereka. ${ }^{12}$

Hal ini pun akan meningkatkan kualitas demokrasi karena sekat antara rakyat dan wakil-wakilnya dapat dikurangi. Demikian halnya, jarak antara proses pengambilan keputusan serta putusan yang diambil tidak terlalu jauh dari aspirasi yang berkembang di masyarakat. Hal penting yang juga perlu diingat bahwa demokrasi yang tengah didengungkan bersama oleh pemerintah dan rakyat Indonesia juga tak lepas dari komitmen pemerintah untuk membuka serta memperluas dialog yang bermakna bagi kepentingan masyarakat. Dengan demikian, masyarakat dilihatkan untuk berperan membentuk agenda setting dalam setiap kebijakan yang dibuat oleh pemerintah.

Merlyna Lim mengatakan bahwa apa yang terjadi di Indonesia pra reformasi merupakan kondisi yang disebut dengan panopticon. ${ }^{13}$ Presiden Soeharto menciptakan sebuah panopticon pengawasan dan ketakutan melalui peraturan baik tertulis maupun lisan yang mengontrol ruang fisik serta ruang mental. Apapun yang orang melangkah atau pikirkan, tidak dapat lolos dari mata pemerintah.

Dengan pengawasan yang ketat dari atas ke bawah regim Orba ala militerisme, menyebabkan ketakutan dalam masyarakat untuk berorganisasi dan menyuarakan pendapat. Suara, input serta pendapat yang terangkum dalam opini publik seringkali juga harus melalui sensor yang terlebih dulu dilakukan oleh media. Media sebagai salah satu entitas juga tak lepas dari kekuatan dan kekuasaan regim Orba, bila terjadi 'pelanggaran versi pemerintah' maka media harus siap untuk ditarik SIUPnya (Surat Ijin Usaha Penerbitan).

Begitu pula dengan organisasi-organisasi yang dipandang mengancam eksistensi pemerintah Orde Baru, secara jelas atas nama stabilitas dan keamanan nasional maka pemerintah dapat membubarkan dengan paksa organisasi tersebut. Globalisasi yang ditandai oleh salah satunya dengan gelombang arus informasi yang tak terbendung lagi berhasil meruntuhkan menara gading pemerintahan Soeharto yang telah berdiri kurang lebih 30 tahun lamanya di Indonesia. kegagalan kebijakan regim Soeharto membangun dasar-dasar politik yang demokratis bagi masyarakat Indonesia. Kritikan yang tajam seringkali dapat ditemukan dalam kolom-kolom opini di internet baik yang dicetuskan oleh cendekiawan Indonesia sendiri. Pada akhirnya tidak hanya masalah krisis ekonomi dan politik saja namun juga berkembang kasuskasus lain menyangkut kekayaan keluarga mantan presiden Soeharto, kolusi dan korupsi pejabat yang secara transparan dikupas secara tuntas di internet.

12 Ibid, hal 52.

${ }^{13}$ Merlyna Lim, “Cyber-civic space In Indonesia, From Panopticon To Pandemonium ?”, hal. 386. 
Pasca reformasi, fenomena ini tetap bertahan, munculnya situs-situs dan mailing list yang secara konsisten membuka forum-forum diskusi dan mengeksplorasi setiap kebijakan politik dan isue-isue lain seperti masalah ekonomi, budaya dan sosial yang nantinya berdampak secara politis juga secara gamblang difloor-kan oleh opinian makers. Apabila diamati, opini-opini yang beredar secara on-line pun terlihat lebih lugas dikritisi oleh para penulis atau aktivis cyberspace.

Hanya sayangnya, kecenderungan ini tidak diikuti oleh mainsteram media lain, misalnya televisi atau radio. Di Surabaya, mungkin cuma Suara Surabaya FM yang menyediakan sebuah program interaksi yang menampung suara pendengar

\section{Wajah Media Dalam Masyarakat (As It Is)}

Globalisasi komunikasi yang berdampak pad ide-ide kebebasan pers tidak hanya berimplikasi pada terkuaknya praktik-praktik liar poltik atau penyelewengan yang dilakukan oleh penguasa namun pada kenyataannya globalisasi juga menjadikan media sebagai 'gigant organism' yang pengaruhnya luar biasa dalam masyarakat. Media menjadi mesin pencetak consiciousness yang mengatur bagaimana setiap orang berpikir, bertutur kata, bersikap dan berperilaku sebagai manusia. Media menciptakan lingkungan manusia yang jauh dari kenyataan dan menghadirkan peristiwa-peristiwa yang menurut istilah Daniel Boorstin ialah unauthentic happenings. Boorstin juga mengungkapkan hal berikut,

In a democratic society.........freedom of speech and of the press and of broadcasting includes freedom to create pseudo events. Competing politicans, newsmen and news media contest in this creation. They vie with each other in offering attractive, 'informative' accounts and images of the world. They are free to speculate on the facts, to bring new facts into being, to demand answers to their own contrived questions. Our 'free market of ideas' is a place where people are confronted by competing pseudo-events and are allowed to judge among them. When we speak of 'imforming' the people this is what we really mean. ${ }^{14}$

Water Lippmann dalam bukunya yang berjudul Public Opinion terbitan tahun 1922 menjelaskan tentang lingkungan semu. Ia mengatakan bahwa dunia obyektif yang dihadapi oleh manusia itu "tak terjangkau, tak terlihat, dan tak terbayangkan."

${ }_{15} \mathrm{Hal}$ ini dimanfaatkan sepenuhnya oleh para politisi melalui kekuasaannya dan akses yang dimilikinya untuk mempengaruhi masyarakat melalui media.

Misalnya saja pada masa Orba, harus diakui bahwa media turut membangun dan mempopulerkan profil Soeharto sebagai Bapak Pembangunan Indonesia melalui pemberitaannya serta mendiskreditkan anak-anak keluarga PKI. Pada masa reformasi yang diklaim sebagai masa kebangkitan demokrasi pasca kemerdekaan RI, ketika media Indonesia turut serta menikmati euforia kebebasan, perilaku media semakin tak terkendali dan jauh dari peran yang seharusnya ia emban.

Media mengakomodir pertarungan atau perang opini dari politisi yang notabene tidak mendidik bahkan membohongi masyarakat. Dalam banyak hal, hanya karena

14 D.J. Boorstin, "The Image", dalam Brian McNair, "An Introduction To Political Communication", hal. 27.

${ }^{15}$ William L. Rivers, et.al., "Media Massa \& Masyarakat Modern”, hal.29. 
alasan ekonomi atau profit, media banyak menampilkan tokoh-tokoh politik untuk memberikan image yang berbeda pada masyarakat. Hal ini pada umumnya banyak terjadi ketika menjelang Pemilu.

Oleh karena itu, orang media ini telah mendistorsi informasi yang hendak disampaikan kepada khalayak dengan menampilkan seolah-olah para kandidat yang berasal dari media itu "lebih memiliki nilai berita" dibandingkan dengan kandidat lainnya. Di sini kita tidak membicarakan audiens atau pemirsa memiliki kecerdikan sendiri dalam mencerna informasi yang disampaikan padanya. Karya Stuart Hall soal encoding-decoding atau Ien Ang tentang active audience untuk sementara bisa dikesampingkan dan digunakan pada konteks pembicaraan lain. Namun, intinya adalah orang media yang memiliki interes politik telah dengan sengaja menggunakan akses besarnya pada media untuk mempromosikan kepentingan politik pribadinya.

Lingkungan semu yang dibentuk oleh media juga dilakukan melalui keberpihakan media terhadap salah satu kandidat. Hal ini dapat dilihat dengan pemberitaan yang tidak cover both sides atau berat sebelah. Saat menampilkan atau memberitakan seorang kandidat yang disukainya, media akan memilih angle-angle yang mampu menarik dan memikat sisi emosional audiensnya. Sebaliknya, media juga dapat memberikan judgement yang negatif kepada kandidat lain sehingga peran media sebagai pembangun opini publik juga tidak lepas dari faktor ekonomi politik media.

\section{Relasi Kapitalisme Media \& Kekuasaan}

Globalisasi memiliki relasi yang erat dengan kapitalisme dan kekuasaan. Globalisasi memungkinkan berperan sebagai akses bagi terjadinya konsentrasi kekuatan organisasi-organisasi besar yang memainkan peran sebagai "player" atau aktor yang mendominasi arus ekonomi, politik, informasi maupun budaya. Fenomena ini terjadi di seluruh belahan dunia termasuk Indonesia, yakni tak dapat dihindarkan lagi terjadinya pola kepemilikkan serta praktik produksi dan distribusi produk media yang terkonsentrasi pada kelompok-kelompok bisnis besar.

Dampak lain dari makin terkonsentrasinya kepemilikan media ini adalah komersialisasi yang makin dominan dalam industri media. Media yang dihasilkannya terus-menerus menghasilkan industri hiburan-yang memudahkan akumulasi modalyang dilawankan dengan kewajiban menunaikan fungsi informasi dan edukasi kepada publik. Orientasi industri media yang ada sekarang banyak bergeser dari urusan jurnalisme publik. Yang marak adalah tayangan infotainment, istilah yang salah kaprah karena anggapannya lalu informasi haruslah menghibur.

Kepemilikan media tanpa disadari juga berdampak terhadap kualitas jurnalistik. Para jurnalis hanya dikondisikan untuk menyajikan berita dan informasi yang sesuai dengan tuntutan redaksi yang notabene selaras dengan permintaan pengiklan atau pemilik media. Jurnalisme pada akhirnya tidak mengakomodir perkembangan wacana-wacana yang lahir di masyarakat ataupun memperdalam kemampuan jurnalis untuk melakukan liputan investigasi misalnya.

Agus Sudibyo dalam karyanya "Ekonomi Politik Penyiaran di Indonesia" menguraikan fenomena kepemilikkan media yang spektakuler di sepanjang tahun 1990-an, yakni perusahaan Bhakti Investama yang menjadi pemilik modal di sejumlah stasiun televisi, seperti RCTI, Global TV, Metro TV, dan TPI. Dari fenomena ini, muncul juga gejala menarik yang berkaitan dengan kepemilikan media dan kepentingan politik si pemilik media tersebut. Misalnya Surya Paloh yang 
menggunakan Media Indonesia dan stasiun Metro TV untuk kampanye dirinya dalam Konvensi Partai Golkar pada Pemilu 2004 serta secara gamblang menyuarakan sikap politik Golkar terkait dengan koalisi Golkar dengan Demokrat pada Pemilu 2009. Pada garis besarnya, orang media yang memiliki interes politik telah dengan sengaja menggunakan akses besarnya pada media untuk mempromosikan kepentingan politik pribadinya.

\section{KESIMPULAN}

Globalisasi merupakan fenomena yang tidak dapat dihindarkan oleh semua negara bangsa di dunia. Globalisasi yang membawa transformasi khususnya di bidang Information \& Communication Technologies (ICTs) memberikan kontribusi bagi demokratisasi di Indonesia. Reformasi yang bergulir pada tahun 1998 dengan ditandai tumbangnya regim Soeharto harus diakui tidak lepas dari teknologi komunikasi yang saat itu masuk ke wilayah tanah air. Satu hal yang juga signifikan dalam mempercepat gelombang reformasi ialah keberadaan internet yang saat itu booming di Indonesia sekitar tahun 1990-an. Fenomena maraknya internet di Indonesia tersebut, seperti yang pernah diungkapkan oleh McLuhan dengan "Global Village". Bahwa tidak ada satu wilayah pun di dunia ini yang terisolasi dari arus informasi yang secara global menjalar dari satu tempat ke tempat yang lain.

Globalisasi komunikasi tersebut tidak dapat dipisahkan dengan entitas media sebagai aktor atau agen yang turut serta menggulirkan fenomena globalisasi. Hal ini harus diakui, bahwa dalam masyarakat modern, media memainkan peranan yang signifikan. Dalam kenyataannya bagai Dewa Jenus, media dihadapkan dengan dualisme. Di satu sisi, media harus mengemban nilai-nilai luhur yang mengabdi kepada kepentingan masyarakat (as ought to be). Idealnya media mampu menjadi fasilitator bagi terjadinya public sphere yang menampung opini masyarakat terhadap suatu isue atau permasalahan bangsa. Dalam wacana Freedom Of Information, sekali lagi media diharapkan mampu mengupas secara transparan tentang penyelewengan kekuasaan yang dilakukan oleh penguasa.

Di sisi lain, media dihadapkan dengan benturan kepentingan ekonomi politik sehingga wajah media menjadi as it is. Hal itu ditandai dengan ketidakmampuan media menyediakan point of view yang beragam yang mencerminkan berbagai kepentingan masyarakat luas. Media cenderung mereduksi pemberitaannya dan mengemasnya dengan angle yang memang dirasakan menguntungkan secara ekonomi. Media Indonesia juga tidak dapat dilepaskan dengan intervensi politik ketika kepemilikan media justru berada di tangan pejabat negara. Kepemilikan tersebut, pada akhirnya mempengaruhi substansi pemberitaan yang akan disebarkan ke masyarakat sehingga independensi media di Indonesia masih merupakan pertanyaan yang tak tahu pasti kapan terjawab.

\section{DAFTAR PUSTAKA}

Hague, Barry N. \& Loader, Brian D., "Digital Democracy : Discource and Decision Making In The Information Age", 1999, $1^{\text {st }}$ Edition, Routledge.

Kurniawan, Nanang Indra, "Kritik Globalisasi \& Neoliberalisme”, 2006, FISIPOLUGM. 
Lim, Merlyna, “Cyber-civic space In Indonesia, From Panopticon To Pandemonium ?”.

Louw, Eric, "The Media And Political Process", 2005, 1t, SAGE.

Rivers, William L., et.al., "Media Massa \& Masyarakat Modern”, 2004, Kencana.

McNair, Brian, "An Introduction To Political Communication", 1999, 2nd Edition, Routledge.

Mendel, Toby, "Kebebasan Memperoleh Informasi, Sebuah Survei Perbandingan Hukum", 2004, edisi pertama Indonesia, UNESCO.

Wilhelm, Anthony, "Demokrasi Di Era Digital, Tantangan Kehidupan Politik di Ruang Cyber", 2003, edisi terjemahan, Routledge.

www.theindonesianinstitute.org, diakses tanggal 16 Januari 2007, pukul 10.10 WIB.

http://www.suaramerdeka.com, diakses tanggal 24 Januari 2007, pukul. 12.00 WIB. 